\title{
Chia (Salvia hispanica) can be used to manufacture sugar-snap cookies with an improved nutritional value
}

\author{
BARRIENTOS, V. A. ${ }^{a}$, AGUIRRE, A. ${ }^{\mathrm{b}, \mathrm{c}}$, AND BORNEO, R...$^{\mathrm{a}, \mathrm{b}^{*}, \mathrm{c}}$ \\ ${ }^{a}$ Centro de Excelencia en Procesos y Productos Córdoba (CEPROCOR). Ministerio Ciencia y Tecnología. \\ Gobierno Provincia de Córdoba. Argentina.

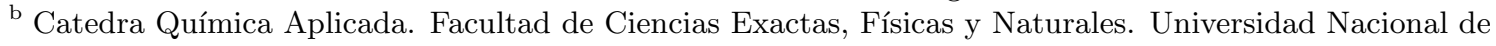 \\ Córdoba. Córdoba, Argentina. \\ ${ }^{\mathrm{c}}$ ICYTAC (CONICET - Universidad Nacional de Córdoba). \\ ${ }^{*}$ Corresponding author \\ rborneo@efn.uncor.edu
}

Received: 16 September 2011; Published online: 18 October 2012

\begin{abstract}
Technologists and nutritionists are always looking for alternative ingredients to use in their formulations to improve functional and nutritional properties. Therefore, cookies using Chia (Salvia hispanica), a grain with high quality nutrients, were prepared. The nutritional value was determined by measuring the chemical composition, mineral content, and the fatty acid composition (saturated, monunsaturated, polyunsaturated, linoleic and linolenic acids). Data obtained from this chemical analysis was used to estimate the nutrients intake and compare them to the dietary reference intakes (DRIs). Cookies supplemented with chia flour contained significantly more protein, fat, crude fiber, calcium, zinc, and alpha-linolenic (n-3) acid. It was estimated that the supplemented cookies would contribute to the corresponding DRIs in the range of $8.1-13.8 \%$ (children) and $6.5-11.0 \%$ (males/females) for calcium; and $14.0-18.0 \%$ (children) and $6.4-11.3 \%$ (males/females) for zinc. The addition of chia flour to the cookies resulted in a product sensorially acceptable with a better fatty acid profile (lower n-6/n-3). Supplemented cookies would contribute to alpha-linolenic DRI in the range of $65.9-134.5 \%$ (children), 49.4-100.9\% (males), and 53.9-110.0\% (females). Dietary intake of protein, fiber, calcium, zinc, and alpha-linolenic (n-3) acid could be increased by the consumption of sugar-snap cookies supplemented with chia flour.
\end{abstract}

Keywords: Chia, sugar-snap cookies, nutritional value

\section{Introduction}

Cereal-based products have an important role in human nutrition. Bakery products are the most traditional transformation products obtained from cereals and considered an excellent source of energy and major nutrients. However, bakery products (cookies, cakes, bread) made from highly refined milling products are reported to be nutritionally poorer than those made from whole cereals (El-Adawy, 1997). There has been an ongoing effort to enhance the nutritional value of different bakery products by means of supplementation with various materials including proteins, minerals, fibre, and different raw foods (Martinez-Navarrete, Camacho, MartinezLahuerta, Martinez-Monzo, \& Fito, 2002; McKevith, 2005; Arshad, Anjum, \& Zahoor, 2007; Singh \& Mohamed, 2007).

Chia (Salvia hispanica L.) was a very important staple food for Mesoamericans in pre- 
Columbians time (Reyes-Caudillo, Tecante, \& Valdivia-Lopez, 2008). Chia has been under cultivation in Mexico for thousands of years. Recent evaluation of its properties and possible uses has shown that it has a high nutricional value, with high contents of linolenic acid, dietary fibre, and protein (Peiretti \& Gai, 2009). Chia seeds have a protein content of $17-24 \%$, a fibre content of 18 $22 \%$ (Ayerza \& Coates, 2000), and a high oil content (25-35\%, Taga, Miller, and Pratt (1984)).

Also, chia seeds are being promoted as an important ingredient for functional foods due to the presence of different bioactive compounds. Chia may be a promising new source of antioxidants due to the presence of polyphenols (ReyesCaudillo et al., 2008). The presence of cinnamic, chlorogenic and caffeic acids, myrcetin, quercetin and kaempferol in extracts of chia seeds has also been reported (Lu \& Foo, 2002). Chia seeds and its meal do not have any of the problems associated with other sources of polyunsaturated fatty acids such as flaxseed or marine products, in regard to strong fishy and/or solvent flavours (Ayerza \& Coates, 2001). Chia has been selected, among several alternative crops, for industrial production by the Northwestern Argentina Regional Project and the favourable growing conditions of the Northwestern part of the country (Ayerza \& Coates, 1996).

Modern western diets are characterized by a high level of omega-6 fatty acids (Simpopoulos, 1995, 2001). An increase in the ratio of omega-6:omega3 fatty acids from values of 1-2:1 in pre-industrial societies to values of 10-20:1 in modern western civilization diets has been reported (Simpopoulos, 2001). Consuming more omega- 6 fatty acids has prothrombotic and pro-aggregative blood effects that may result in an increased risk of cardiovascular disease. According to a FAO/WHO report a well-balanced diet should have an n-6/n3 ratio of 5:1 or lower (FAO/WHO, 1994). An increase in the consumption of foods supplemented with raw materials rich in omega- 3 fatty acids could have positive results in health.

Different countries have different consumption levels of cookies. In Argentina, cookie consumption is traditional, and in 2007, annual per capita consumption of cookies was of 8.4 kilograms which represented a $13.9 \%$ increase from the previous year. The average per capita daily con- sumption of cookies was estimated at $50 \mathrm{~g}$ based on production statistics (Lezcano, 2008) and inter-annual production growth to date. This daily portion could be even higher for certain population groups (children for example) since cookies are one of their favourite food snacks during school time or at home.

In this study supplementation of cookies with chia at two levels $(10 \%$ and $20 \%$ on a flour basis) was performed to investigate the contribution of the supplemented cookies to meeting the dietary reference intakes (DRIs) for various nutrients (fat, protein, minerals, fatty acids). In addition to the chemical composition analysis, including macro and micronutrients, fatty acids, as well as the adequacy of the supplemented cookies, we studied the effect of adding chia seeds to the product sensory preference, product colour, and texture. To the best of our knowledge this is the first time an investigation is carried out to evaluate the effect of supplementation of cookies with chia. Justo et al. (2007) developed a bread made with soybean, linseeds, and folic acid. We expect to be able to manufacture sugarsnap cookies with an improved nutritional value by using chia seeds.

\section{Materials and Methods}

\subsection{Materials}

Wheat flour (white, $10 \%$ protein, enriched; Molino San José, Córdoba, Argentina), sucrose (granulated; Ingenio Fronterita, Tucumán, Argentina), vegetable shortening (Molino Cañuelas, Córdoba, Argentina), powdered whole milk (La Serenísima, Buenos Aires, Argentina), chia seeds flour (Grandiet, Córdoba, Argentina), sodium bicarbonate powder (Yuspe, Córdoba, Argentina), and table salt (Celusal, Industrias Químicas y Mineras Timbó, Buenos Aires, Argentina) were all obtained locally. All reagents used in this study were of analytical grade and were purchased from local suppliers.

\subsection{Cookie preparation}

Cookies were prepared according to the method of (León, Rubiolo, \& Añon, 1996). The cookie 
formula was: wheat flour $45.0 \mathrm{~g}$, sucrose $27.0 \mathrm{~g}$, vegetable shortening $20.2 \mathrm{~g}$, powdered whole milk $2.3 \mathrm{~g}$, sodium bicarbonate $0.5 \mathrm{~g}$, salt $0.4 \mathrm{~g}$, distilled water $8.5 \mathrm{~g}$. Cookies were supplemented by replacing wheat flour with chia seeds flour at 10 and $20 \%$ on a flour basis. Bake trials were carried out on under laboratory conditions (room temperature was kept controlled at $20-22^{\circ} \mathrm{C}$ throughout the manufacturing process). Dough mixing and baking were performed on laboratory-scale equipment. Sugar, powdered milk, salt, and bicarbonate were mixed (Phillips blender, model RH 1945; Philips, Argentina) for $30 \mathrm{sec}$ at slow speed. Shortening was added and mixed for 2 min (low speed). Afterwards, water was added and continued to mix for $1 \mathrm{~min}$. Finally, wheat flour (or a blend of wheat flour-chia seeds flour) was added and continued to mix for $2 \mathrm{~min}$. The dough was then hand rolled into a cylinder of 10 $\mathrm{cm}$ length (approximately) and placed between two wood sticks separated by $5 \mathrm{~cm}$ (height $7 \mathrm{~mm}$ ). Using a dough roller, 12 passages were made. Four dough discs were cut with a cookie cutter (45mm diameter). Discs were transferred to a baking tray. With the remaining dough a small cylinder was formed again and the procedure was repeated so as to obtain two more cookie discs. The six discs were baked for $10 \mathrm{~min}$ at $180^{\circ}$ in a gas-fired oven (Cyclo Ingenieria, Argentina). The baking was repeated three times (on 3 different days) so as to have three true replicates.

\subsection{Chemical analyses}

Water content (Official Method No 926.5), fat (Official Method No 950.37), protein (Official Method No 950.36), ash (Official Method No 930.22), fatty acid composition (Official Method No 996.06), and crude fibre content (Official Method No 950.37) were determined by standard methods of analysis (AOAC, 2000). Mineral content was determined by atomic absorption spectroscopy in wet acid-digested samples (Zachariadis, Raidou, Themelis, \& Stratis, 2002).

\subsection{Quality assessment}

Cookie firmness was estimated using a TA.XT2i Texture Analyser (Stable Microsystems, Surrey,
UK) using a HDP/3PB probe. Force was measured in compression mode (test speed $1 \mathrm{~mm} / \mathrm{s}$ ) until the cookie broke (breaking point). Maximum force $(\mathrm{g})$ to break the cookie was recorded. Colour was measured using a Minolta spectrophotometer (model CM-500d series, Minolta Co, Japan). Results were expressed with the CIE $\mathrm{L}^{*} \mathrm{a}{ }^{*} \mathrm{~b}^{*}$ colour space and were obtained using the D65 standard illuminant and the $2^{\circ}$ standard observer. Colour determinations were made $3 \times 3$ times in each cookie: colour was checked on each cookie at three different points (centre and $1 \mathrm{~cm}$ of each side along cookie diameter) and every point was measured three times.

\subsection{Sensory evaluation}

Cookies samples were evaluated 24 hours after baking. Sixty-five untrained panellists evaluated the overall degree of liking of the samples. Participants were given a nine-point hedonic scale which consisted of the following ratings: 1 (dislike extremely), 2 (dislike very much), 3 (dislike moderately), 4 (dislike slightly), 5 (neither dislike nor like), 6 (like slightly), 7 (like moderately), 8 (like very much), and 9 (like extremely). They completed paper ballots that contained the hedonic scales and instructions. The samples were identified with a three-digit code numbers and were served in random order. Participants were instructed to rank each sample individually and not to rank the samples against each other. Prior to the evaluation each participant was informed about the scope of the test without revealing information that might compromise its validity. All participants were cookie consumers before but no information was collected on preferences for cookie type or flavour preferences. Water was provided for palate cleansing between sample testing.

\subsection{Statistical analyses}

Analyses were performed in triplicate. Means and standard deviations were calculated. Analysis of variance (ANOVA) was used to detect significant differences among treatments (3 treatments: control cookies, $10 \%$ chia supplementation, $20 \%$ chia supplementation). Least signif- 
icant differences were calculated using the Fischer's test. A significance level of 0.05 was used for all statistical analyses. Data were analyzed using the SAS statistical software (SAS, 1994).

\section{Results and discussion}

\subsection{Macronutrient contents of cookies}

A protein content of $7.55 \mathrm{~g} / 100 \mathrm{~g}$ (all data presented on a dry basis) was obtained for sugar-snap cookies made with wheat flour (control). The protein content increased significantly among chia-supplemented cookies (Table 1). The fat content of sugar-snap cookies was $22.42 \mathrm{~g} / 100$ g. Fat contents increased as the level of supplementation with chia increased. Observed differences were statistically significant $(\mathrm{p}<0.05)$. These differences were due to the high content of oil and protein of chia seeds (Peiretti \& Gai, 2009). Ash content of control cookies was $1.37 \mathrm{~g} / 100 \mathrm{~g}$ (Table 1). Supplementation with chia increased the ash content of cookies. Those differences were statistically significant $(\mathrm{p}<0.05)$. Fibre crude contents also increased with increased levels of chia as compared to the control samples. Cookies supplemented with $20 \%$ chia had 4.9 times more inorganic material (ash) than control samples. Carbohydrate content decreased as chia is incorporated in the cookie formulation (Table 1 ) because chia seeds, containing less carbohydrate (more protein and oil than wheat flour), replaced part of the wheat flour in the cookie formulation.

\subsection{Micronutrient contents of cookies}

Sugar-snap cookies had $2.54 \mathrm{mg}$ of iron/100g of $0.12 \mathrm{mg}$ of copper $/ 100 \mathrm{~g}, 0.58 \mathrm{mg}$ of zinc $/ 100 \mathrm{~g}$, $109.01 \mathrm{mg}$ of potassium $/ 100 \mathrm{~g}, 317.9 \mathrm{mg}$ of sodium /100g, $34.79 \mathrm{mg}$ of calcium /100g, and $14.91 \mathrm{mg}$ /100g (Table 2, all data expressed on a dry basis). The addition of chia to cookies did not significantly increase the contents of copper, potassium, and sodium. Chia supplemented cookies exhibited significantly higher contents of zinc and calcium at all levels of supplementation. Cookies supplemented with chia (10\%) had 1.87 times more calcium than the control and cookies made with $20 \%$ chia had 3.17 times more calcium when compared to the control cookies. Iron and magnesium decreased significantly as the supplementation with chia increased (Table 2).

\subsection{Fatty acids composition of supplemented cookies}

The analysis of fatty acids composition of sugarsnap cookies shows that cookies have $5.62 \mathrm{~g}$ of saturated fat $/ 100 \mathrm{~g}, 8.64 \mathrm{~g}$ of monounsaturated fat $/ 100 \mathrm{~g}, 6.14 \mathrm{~g} / 100 \mathrm{~g}, 5.72 \mathrm{~g}$ of linoleic (n-6) acid $/ 100 \mathrm{~g}$, and $0.39 \mathrm{~g}$ of alpha-linolenic (n-3) acid /100g (all data presented on a dry basis). The inclusion of chia seeds in the sugar-snap formulation increased the contents of all fatty acids categories measured in this study. All differences were statistically significant $(\mathrm{p}<0.05$, Table 3$)$. The increase of alpha-linolenic (n-3) was not only statistically significant (Table 3 ) but also significant in terms of the amount of the increase. Cookies supplemented with chia $(10 \%, 20 \%)$ had 3.05 and 6.20 times more alpha-linolenic acid than the control cookies. Table 3 shows that supplementation of sugar-snap cookies with chia seeds reduced the omega-6/omega-3 ratio from 15.1 (control) to 2.8. Undoubtedly, the high content of omega- 3 fatty acids present in chia is responsible for a better fatty acid profile in chia supplemented cookies. As mentioned in the introduction a well-balanced diet should have an n-6/n-3 ratio of 5:1 or lower (FAO/WHO, 1994).

\subsection{Nutritional adequacy of cookies}

To estimate the nutritional adequacy of cookies supplemented with chia, the contribution of a daily per capita portion of cookies $(50 \mathrm{~g})$ to the intake of macro and micronutrients was estimated and compared to the dietary reference intakes (DRIs) for male, female, and children (4-8 years) life stage groups (IOM, 2009). 
Cookies supplemented with Chia $\mid 139$

Table 1: Chemical composition of cookies prepared with wheat flour and two levels of Salvia hispanica seeds flour ${ }^{1}$

\begin{tabular}{lcccccc}
\hline & $\begin{array}{c}\text { Moisture } \\
(\mathrm{g} / 100 \mathrm{~g})\end{array}$ & $\begin{array}{c}\text { Protein } \\
(\mathrm{g} / 100 \mathrm{~g})\end{array}$ & $\begin{array}{c}\text { Fat } \\
(\mathrm{g} / 100 \mathrm{~g})\end{array}$ & $\begin{array}{c}\text { Ash } \\
(\mathrm{g} / 100 \mathrm{~g})\end{array}$ & $\begin{array}{c}\text { Crude fiber } \\
(\mathrm{g} / 100 \mathrm{~g})\end{array}$ & $\begin{array}{c}\text { Carbohydrate* }^{*} \\
(\mathrm{~g} / 100 \mathrm{~g})\end{array}$ \\
\hline Control & $3.96 \pm 0.04 \mathrm{a}$ & $7.55 \pm 0.05 \mathrm{a}$ & $22.42 \pm 0.01 \mathrm{a}$ & $1.37 \pm 0.02 \mathrm{a}$ & $0.66 \pm 0.04 \mathrm{a}$ & 64.04 \\
$10 \%$ Chia flour & $4.43 \pm 0.04 \mathrm{~b}$ & $8.72 \pm 0.05 \mathrm{~b}$ & $23.05 \pm 0.01 \mathrm{~b}$ & $1.78 \pm 0.02 \mathrm{~b}$ & $1.89 \pm 0.04 \mathrm{~b}$ & 60.13 \\
$20 \%$ Chia flour & $6.09 \pm 0.04 \mathrm{c}$ & $10.44 \pm 0.05 \mathrm{c}$ & $25.02 \pm 0.01 \mathrm{c}$ & $2.34 \pm 0.02 \mathrm{c}$ & $3.24 \pm 0.04 \mathrm{c}$ & 58.96 \\
\hline
\end{tabular}

${ }^{1}$ Means \pm SD of three independent analyses. All data expressed on a dry basis. Different letters in the same column indicate that means were significantly different $(\mathrm{p}<0.05)$.

*calculated by difference

Table 2: Mineral content of cookies prepared with wheat flour and two levels of Salvia hispanica seeds flour ${ }^{1}$

\begin{tabular}{lccccccc}
\hline Cookie Samples & \multicolumn{7}{c}{ Mineral Content $(\mathrm{mg} / 100 \mathrm{~g})$} \\
\cline { 2 - 8 } & $\mathrm{Fe}$ & $\mathrm{Cu}$ & $\mathrm{Zn}$ & $\mathrm{K}$ & $\mathrm{Na}$ & $\mathrm{Ca}$ & $\mathrm{Mg}$ \\
\hline Control & $2.54 \pm 0.25 \mathrm{a}$ & $0.12 \pm 0.07 \mathrm{a}$ & $0.58 \pm 0.18 \mathrm{a}$ & $109.01 \pm 12 \mathrm{a}$ & $317.91 \pm 19 \mathrm{a}$ & $34.79 \pm 0.10 \mathrm{a}$ & $14.91 \pm 0.33 \mathrm{a}$ \\
$10 \%$ Chia flour & $2.30 \pm 0.20 \mathrm{a}$ & $0.12 \pm 0.05 \mathrm{a}$ & $0.69 \pm 0.18 \mathrm{~b}$ & $109.22 \pm 10 \mathrm{a}$ & $316.82 \pm 15 \mathrm{a}$ & $64.97 \pm 0.13 \mathrm{~b}$ & $13.59 \pm 0.31 \mathrm{~b}$ \\
$20 \%$ Chia flour & $1.95 \pm 0.15 \mathrm{~b}$ & $0.12 \pm 0.06 \mathrm{a}$ & $0.92 \pm 0.15 \mathrm{c}$ & $109.50 \pm 15 \mathrm{a}$ & $317.66 \pm 20 \mathrm{a}$ & $110.21 \pm 0.20 \mathrm{c}$ & $11.69 \pm 0.32 \mathrm{c}$ \\
\hline
\end{tabular}

${ }^{1}$ Means \pm SD of three independent analyses. All data expressed on a dry basis. Different letters in the same column indicate that means were significantly different $(\mathrm{p}<0.05)$.

Table 3: Fatty acid composition of cookies prepared with wheat flour and two levels of Salvia hispanica seeds flour ${ }^{1}$

\begin{tabular}{|c|c|c|c|c|c|c|}
\hline & $\begin{array}{l}\text { Saturated fat } \\
(\mathrm{g} / 100 \mathrm{~g})\end{array}$ & $\begin{array}{l}\text { Monounsaturated } \\
\text { fat }(\mathrm{g} / 100 \mathrm{~g})\end{array}$ & $\begin{array}{l}\text { Polyunsaturated } \\
\text { fat }(\mathrm{g} / 100 \mathrm{~g})\end{array}$ & $\begin{array}{l}\text { Linoleic }(\mathrm{n}-6) \\
(\mathrm{g} / 100 \mathrm{~g})\end{array}$ & $\begin{array}{l}\text { Alpha-Linolenic } \\
(\mathrm{n}-3)(\mathrm{g} / 100 \mathrm{~g})\end{array}$ & $\begin{array}{c}\text { Ratio } \\
(\mathrm{n}-6 / \mathrm{n}-3)\end{array}$ \\
\hline Control & $5.62 \pm 0.03 \mathrm{a}$ & $8.64 \pm 0.01 \mathrm{a}$ & $6.14 \pm 0.05 \mathrm{a}$ & $5.72 \pm 0.01 \mathrm{a}$ & $0.39 \pm 0.01 \mathrm{a}$ & 15.1 \\
\hline 10\% Chia flour & $5.75 \pm 0.01 b$ & $8.79 \pm 0.01 b$ & $7.12 \pm 0.06 \mathrm{~b}$ & $5.97 \pm 0.00 \mathrm{~b}$ & $1.19 \pm 0.05 b$ & 5.0 \\
\hline $20 \%$ Chia flour & $6.07 \pm 0.00 \mathrm{c}$ & $9.05 \pm 0.01 \mathrm{c}$ & $8.83 \pm 0.02 c$ & $6.42 \pm 0.07 \mathrm{c}$ & $2.42 \pm 0.10 \mathrm{c}$ & 2.8 \\
\hline
\end{tabular}

${ }^{1}$ Means \pm SD of three independent analyses. All data expressed on a dry basis. Different letters in the same column indicate that means were significantly different $(\mathrm{p}<0.05)$.

\section{Macronutrients intake}

Table 4 summarizes the ratios (in percentage) of the average intakes of macronutrients to the respective DRIs taken from the Institute of Medicine (IOM, 2009). An average daily portion of sugar-snap cookies (control) contributes to the intake of proteins: $19.1 \%$ of DRI of children (4-8 years), $6.5 \%$ of DRI of males, and $7.9 \%$ of DRI of females. The addition of chia seeds to cookies increases the contribution to DRIs for proteins and fats (for all life stage groups) while decreases the contribution to DRIs for carbohydrates (Table 4). Supplementation with chia also increases significantly the intake of alpha-linolenic (n-3) fatty acids. On average cookies supplemented with chia had 6.2 times more n- 3 fatty acids than control cookies. Supplementation of cookies with chia increased significantly (Table 4) the contri- bution to meet the DRI of alpha-linolenic. In fact, children would get $134.5 \%$ of the DRI if a daily ration were consumed. Males would meet their DRI at $100 \%$ for this fatty acid with the $50 \mathrm{~g}$ daily ration and females would get $110 \%$ (Table 4). Thus, cookie supplementation with chia seems to be an efficient and easy way to improve the contribution to meet the DRI of alphalinolenic acid in all age groups. Linoleic (n-6) content and its contribution to meet this fatty acid DRI increased slightly with chia supplementation (Table 4).

\section{Micronutrients intake}

Table 4 displays the contribution to the DRIs of minerals of chia supplemented cookies. Only minerals that showed statistically significant dif- 
Table 4: Contribution of different nutrients intakes to relevant DRIs for an average cookie portion (50 g)

\begin{tabular}{|c|c|c|c|c|c|}
\hline & & \multicolumn{4}{|c|}{ Contribution to DRIs (\%) } \\
\hline Macronutrient & Life Stage Group & $\begin{array}{c}\text { DRIs } \\
\text { (g/day) }\end{array}$ & Control & $10 \%$ Chia flour & $20 \%$ Chia flour \\
\hline \multirow[t]{3}{*}{ Proteins } & Children $4-8$ years & 19 & 19.1 & 21.9 & 25,8 \\
\hline & Male & 56 & 6.5 & 7.4 & 8,8 \\
\hline & Female & 46 & 7.9 & 9.1 & 10,7 \\
\hline Carbohydrates & Children/Male/Female & 130 & 24.9 & 24.0 & 21.3 \\
\hline Fat & Children/Male/Female & 30 & 36.9 & 35.7 & 39.2 \\
\hline \multirow{3}{*}{ Linoleic (n-6) } & Children $4-8$ years & 10 & 28.6 & 29.9 & 32.1 \\
\hline & Male & 17 & 16.8 & 17.6 & 18.9 \\
\hline & Female & 12 & 23.8 & 24.9 & 26.7 \\
\hline \multirow{3}{*}{ Alpha linolenic (n-3) } & Children $4-8$ years & 0.9 & 21.9 & 65.9 & 134.5 \\
\hline & Male & 1.2 & 16.4 & 49.4 & 100.9 \\
\hline & Female & 1.1 & 17.9 & 53.9 & 110.0 \\
\hline \multicolumn{2}{|l|}{ Micronutrients } & $\begin{array}{c}\text { DRIs } \\
\text { (mg/day) }\end{array}$ & & & \\
\hline \multirow[t]{2}{*}{$\mathrm{Ca}$} & Children $4-8$ years & 800 & 4.4 & 8.1 & 13.8 \\
\hline & Male/Female & 1000 & 3.5 & 6.5 & 11.0 \\
\hline \multirow[t]{3}{*}{$\mathrm{Mg}$} & Children $4-8$ years & 130 & 11.5 & 10.5 & 9.0 \\
\hline & Male & 420 & 3.6 & 3.2 & 2.8 \\
\hline & Female & 320 & 4.7 & 4.7 & 3.7 \\
\hline \multirow[t]{3}{*}{$\mathrm{Fe}$} & Children $4-8$ years & 10 & 25.4 & 23.0 & 19.5 \\
\hline & Male & 8 & 31.8 & 28.8 & 24.4 \\
\hline & Female & 18 & 14.1 & 12.8 & 10.8 \\
\hline \multirow[t]{3}{*}{$\mathrm{Zn}$} & Children $4-8$ years & 5 & 12.0 & 14.0 & 18.0 \\
\hline & Male & 11 & 5.5 & 6.4 & 8.2 \\
\hline & Female & 8 & 7.5 & 8.8 & 11.3 \\
\hline
\end{tabular}

ferences in content among cookies (reported on Table 2) are included on Table 4. Statistically significant differences due to supplementation were observed for calcium, magnesium, iron and zinc. Control cookies meets children's daily requirement for $\mathrm{Ca}, \mathrm{Mg}, \mathrm{Fe}$, and $\mathrm{Zn}$ by $4.4 \%$, $11.5 \%, 25.4 \%$, and $12 \%$ respectively. Supplementation with chia flour increased significantly the contribution to meet DRIs for $\mathrm{Ca}$ and $\mathrm{Zn}$, while decreased the contribution to meet DRIs for Fe and $\mathrm{Mg}$. The same trend is observed for males and females DRIs.

\subsection{Sensory Evaluation and Physical Characteristics}

Table 5 shows the overall liking preferences of cookies supplemented with chia. The degree of liking was the highest for the cookie control formulation (7.82) while the lowest was for cookies supplemented with chia seed flour at $20 \%$ level (6.25). No statistical significant difference $(\mathrm{p}<0.05)$ was observed between the control cookies and the cookies supplemented at the $10 \%$ level (Table 5). The 20\% supplemented cookie was statistically and significantly different from 
Cookies supplemented with Chia $\mid 141$

Table 5: Sensory and physical characteristics of cookies prepared with wheat flour and two levels of Salvia hispanica seeds flour ${ }^{1}$

\begin{tabular}{lccccc}
\hline & Liking score & Firmness $(\mathrm{g})$ & \multicolumn{3}{c}{ Colour } \\
\cline { 4 - 6 } & & & $\mathrm{L}^{*}$ & $\mathrm{a}^{*}$ & $\mathrm{~b}^{*}$ \\
\hline Control & $7.82 \pm 0.01 \mathrm{a}$ & $7171 \pm 1364 \mathrm{a}$ & $72 \pm 4 \mathrm{a}$ & $6.3 \pm 0.5 \mathrm{a}$ & $29 \pm 2 \mathrm{a}$ \\
$10 \%$ Chia flour & $7.32 \pm 0.01 \mathrm{a}$ & $5703 \pm 1332 \mathrm{~b}$ & $63 \pm 2 \mathrm{~b}$ & $5.4 \pm 1.1 \mathrm{~b}$ & $24 \pm 1 \mathrm{~b}$ \\
$20 \%$ Chia flour & $6.25 \pm 0.01 \mathrm{~b}$ & $5217 \pm 575 \mathrm{ab}$ & $56 \pm 1 \mathrm{c}$ & $5.4 \pm 0.8 \mathrm{~b}$ & $21 \pm 1 \mathrm{c}$ \\
\hline
\end{tabular}

${ }^{1}$ Means \pm SD of three independent analyses. All data expressed on a dry basis. Different letters in the same column indicate that means were significantly different $(\mathrm{p}<0.05)$.

the rest $(\mathrm{p}<0.05)$. As chia supplementation increased the liking score decreased. Although chia supplementation did affect panellist's preference, no sample received a liking score less than 6.0 (corresponding to the "like slightly" rating category). This means that although the cookies made with chia are less preferred than the control they are not rejected either. The reduction in cookie preference for samples with chia seeds could be explained by the changes seen in certain physical characteristics. In addition to sensory evaluation, Table 5 also shows the difference in colour and texture (firmness) of the cookies. Colour was measured using the CIE $\left(\mathrm{L}^{*} \mathrm{a}^{*} \mathrm{~b}^{*}\right.$ colour space) system. With this method the $\mathrm{L}^{*}$ parameter denotes the luminosity of the sample (as $\mathrm{L}^{*}$ decreases samples are darker), $\mathrm{a}^{*}$ the balance on the red-green axis (as the value of $a^{*}$ increases sample is reddish), and $b^{*}$ the balance on yellow-blue axis (as $b^{*}$ increases the sample becomes yellowish). Values of both $\mathrm{L}^{*}, \mathrm{a}^{*}$, and $b^{*}$ decreased as the content of chia flour increased in the cookie formulation (Table 5), which means that cookies made with chia flour become darker (lower $\mathrm{L}^{*}$ ), with less of a reddish tone (lower values of $\mathrm{a}^{*}$ ) and less yellowish (more bluish). The net effect is darker cookies with subdued colours in samples supplemented with chia. This may have had a definite effect on the reduction of preference for these cookies. Colour and texture are, according to (Delcour \& Hoseney, 2010), important physical quality characteristic of cookies. Firmness (measured as maximum force at breaking point) decreased as cookies had more chia flour in their formulation. This basically means that cookies made with chia flour are of a softer texture and this "softness" may have had a negative effect of cookie preference.

The sensory evaluation of cookies supplemented with chia showed that as the supplementation level increased there is a decrease in the preference for the product. However, even at the highest supplementation level (20\%) the average preference rating was above 6.0 (which correspond to the "like slightly" rating category). This fact shows that supplemented cookies are not rejected by a panel of consumers. Differences in colour (darker cookies with subdued tones) and texture (softer product) may explain the decrease in preference for chia supplemented cookies. Besides the sensory properties, chia supplemented cookies were more acceptable in many nutritional aspects as they contained significantly higher amounts of essential fatty acids and certain minerals $(\mathrm{Ca}, \mathrm{Zn})$. Consumption of cookies supplemented with chia could be beneficial for improving the nutritional status of the general population, especially in children who may ingest more cookies than the average daily portion estimated in this study.

\section{Conclusions}

The physical, chemical, sensory, and nutritional analyses of chia supplemented cookies showed that it is possible to manufacture a product with acceptable properties. Although a scale-up trial would be necessary for evaluating the manufacturing feasibility of producing these cookies at an industrial level, we did not find any processing difficulty in manufacturing sugar-snap cookies with added chia at the levels we used in 
this study. Cookies supplemented with chia contained significantly more protein, fat, crude fiber, calcium, zinc, and alpha-linolenic (n-3) acid. The dietary intake (DRI) of protein, fiber, calcium, zinc, and alpha-linolenic (n-3) acid could be increased by the consumption of sugar-snap cookies supplemented with chia seeds.

\section{References}

AOAC. (2000). Official methods of analysis of the association of official analytical chemists. $17^{\text {th }}$ Edition. Washington DC, AOAC.

Arshad, M. U., Anjum, F. M., \& Zahoor, T. (2007). Nutritional assessment of cookies supplemented with defatted wheat germ. Food Chemistry, 102(1), 123-128. doi:10. 1016/j.foodchem.2006.04.040

Ayerza, R, \& Coates, W. (2000). Dietary levels of chia: influence on yolk cholesterol, lipid content and fatty acid composition for two strains of hens. Poultry Science, 79 (5), 724-739.

Ayerza, R., \& Coates, W. (1996). New industrial crops: northwestern argentina regional project. in: Progress in New Crops, (pp. 4552). (J. Janck, editor.) Alexandria: ASHS Press.

Ayerza, R, \& Coates, W. (2001). Omega-3 enriched eggs: the influence of dietary alphalinolenic fatty acid source on egg production and composition. Canadian Journal Of Animal Science, 81(3), 355-362. doi:10. 4141/A00-094

Delcour, J. A., \& Hoseney, R. C. (2010). Principles of cereal science and technology authors provide insight into the current state of cereal processing. Cereal Foods World, 55(1), 21-22. doi:10.1094/CFW-55-1-0021

El-Adawy, T. (1997). Effect of sesame seed protein supplementation on the nutritional, physical, chemical and sensory properties of wheat flour bread. Food Chemistry, 59(1), 7-14. doi:10.1016/0308-8146(95) 00197-2

FAO/WHO. (1994). Fats and oils in human nutrition. FAO Food and Nutrition papers, 57. Rome: Food and Agriculture Organization.
IOM. (2009). Institute of medicine board. DRI tables. Retrieved from http://fnic.nal.usda. gov / nal_display / index . php ? info_center $=$ $4 \&$ tax_level $=2 \&$ tax_subject $=256 \&$ topic $\mathrm{id}=1342$

Justo, M., Castro Alfaro, A. D., Camarena Aguilar, E., Wrobel, K., Wrobel, K., Alanis Guzman, G., ... Zanella, V. d. M. (2007). Integral bread development with soybean, chia, linseed, and folic acid as a functional food for woman. Archivos Latinoamericanos De Nutricion, 57(1), 78-85.

León, A., Rubiolo, A, \& Añon, M. (1996). Use of triticale flours in cookies: quality factors. Cereal Chemistry, 73(6), 779-784.

Lezcano, E. (2008). Galletitas y bizcochos, perfiles productivos. alimentos argentinos. Retrieved from http : / / www . alimentosargentinos .gov . ar / 0-3/revistas / r_41 / cadenas_ingles / Farinaceos_Cookies_ biscuits.htm

Lu, Y., \& Foo, L. (2002). Polyphenolics of salvia - a review. Phytochemistry, 59(2), 117-140. doi:10.1016/S0031-9422(01)00415-0

Martinez-Navarrete, N, Camacho, M., MartinezLahuerta, J, Martinez-Monzo, J, \& Fito, P. (2002). Iron deficiency and iron fortified foods - a review. Food Research International, 35(2-3), 225-231. doi:10.1016/ S0963-9969(01)00189-2

McKevith, B. (2005). Nutritional aspects of oilseeds. british nutrition foundation nutrition bulletin. British Nutrition Foundation Nutrition Bulletin, 30 (1), 13-26.

Peiretti, P. G., \& Gai, F. (2009). Fatty acid and nutritive quality of chia (Salvia hispanica L.) seeds and plant during growth. Animal Feed Science And Technology, 148(24), 267-275. doi:10.1016/j.anifeedsci.2008. 04.006

Reyes-Caudillo, E., Tecante, A., \& ValdiviaLopez, M. A. (2008). Dietary fibre content and antioxidant activity of phenolic compounds present in mexican chia (Salvia hispanica L.) seeds. Food Chemistry, 107(2), 656-663. doi:10.1016/j.foodchem.2007.08. 062

SAS. (1994). SAS statistical analysis software (version 6.12). SAS Institute Inc. Cary, NC, USA. 
Cookies supplemented with Chia $\mid 143$

Simpopoulos, A. (2001). Essential fatty acids in health and chronic diseases. in, Modern aspects of nutrition, present knowledge, and future perspectives (ie imadfa, e anklam, js konig editors). basel. karger., 66-70.

Simpopoulos, A. (1995). Evolutionary aspects of diet: fatty acids, insulin resistance and obesity. in Obesity: New Directions In Assessments and Management, (pp. 241-261). (AP Simpopoulos, TB VanItallie, editors). Philadelphia. Charles Press.

Singh, M., \& Mohamed, A. (2007). Influence of gluten-soy protein blends on the quality of reduced carbohydrates cookies. Lwt-food Science And Technology, 40(2), 353-360. doi:10.1016/j.lwt.2005.09.013

Taga, M., Miller, E., \& Pratt, D. (1984). Chia seeds as a source of natural lipid antioxidants. Journal of the American Oil Chemists' Society, 61, 928-931. doi:10 . 1007/BF02542169

Zachariadis, G., Raidou, E., Themelis, D., \& Stratis, J. (2002). Determination of mineral content of active dry yeast used in pharmaceutical formulations. Journal Of Pharmaceutical And Biomedical Analysis, 28(34), 463-473. doi:10.1016/S0731-7085(01) 00601-X 